\title{
Realistic expectations and prosocial behavioural intentions to the early phase of the COVID-19 pandemic in the Norwegian population
}

\author{
Bjørn Sætrevik \\ Operational Psychology Research Group, Faculty of Psychology, University of Bergen, Norway
}

\begin{abstract}
The coronavirus pandemic represents a serious challenge for modern societies. Individuals' perception of risk influences their choice of action, and their collective actions determine the societal impact of the pandemic. The current data paper presents descriptive statistics of a survey from a representative sample of Norwegian citizens ( $N=4,083)$, collected in the early phases of the pandemic (March 20-29, 2020). Most of the population considered the risk for being infected to be small and the risk for becoming seriously ill to be smaller still. On the other hand, most were worried that family members could be infected, and that their daily life could change drastically. The majority of participants were optimistic that they could handle the challenges that the virus would bring, and that they would receive good medical treatment if they were to become sick. Almost all stated that they intended to comply with the authorities' advice for limiting the contagion. Most stated that following the advice would be effective in preventing themselves and others from becoming sick. Most stated being careful in how they gather information about the pandemic. The survey showed that the Norwegian population at the time had realistic perceptions of risks, optimistic attitudes and intentions for prosocial behaviour that would limit the pandemic spread.
\end{abstract}

Keywords: coronavirus; COVID-19; perceived risk; behavioural intentions; optimism 


\section{Introduction}

The coronavirus (SARS2-CoV-2, causing the infectious disease COVID-19), is the most serious pandemic to affect the modern Western world yet. This presents an exceptional and unprecedented situation for the general population. The research literature typically assumes that the extent of perceived threat influences what actions the public takes to mitigate the risk (Bish \& Michie, 2010; van der Pligt, 1998). The accumulation of individual responses constitutes how the population responds to the pandemic, and is thus an important factor for a pandemic's societal outcome.

\subsection{Psychological variables relevant for recent pandemics}

Social science research on recent pandemics in Western societies have often focused on the extent to which the public see the pandemic as a threat, and how this may motivate behaviour. Three consecutive crosssectional representative online surveys in the Netherlands during the N1H1 pandemic of 2009 (Bults et al., 2011) found that perceived risk, self-efficacy and compliance decrease over time, while anxiety first decreased but then remained stable. Demographics, trait anxiety, trait avoidance and attention to pandemic media predicted compliance with public health advice. In a hypothetical pandemic scenario (Barr et al., 2008) those perceiving a higher risk were more willing to comply with wearing face masks and being vaccinated. Other studies (Jones \& Salathé, 2009; Rubin et al., 2009) have shown that expressing anxiety for an epidemic mediates the likelihood of engaging in protective behaviour. Exploration of attitudes, knowledge and behaviour over time during the N1H1 pandemic in Germany (Walter et al., 2012), showed differences over time and between sub-groups in information-seeking and willingness to be vaccinated. In a review of the research on behavioural determinants of the N1H1 pandemic, Bish and Michie (2010) found that older, female and more educated participants who see the disease as more severe were more likely to engage in protective behaviour.

Some recent work on the COVID-19 pandemic has also emphasized the role of perceived risk. A US survey panel collected March 26-30 2020 (American Perspectives Survey, 2020) found that a majority reported being worried about becoming infected. A longitudinal US survey collected March 11-16 2020 (Wise et al., 2020) found substantial variation in perceived risk and willingness to engage in protective behaviour, that these increased over the week of measurement, and that perceived risk predicted protective behaviour. A non-representative Norwegian sample $(\mathrm{n}=8,675)$ found that perceiving measures as effective and the outbreak as serious was associated with complying with infection advice (Zickfeld et al., 2020).

In addition to perceived risk, studies of the current pandemic have also indicated that individual variation in personality, attitude and cognitive traits may impact perceived risk and behavioural intentions. A Danish representative study (Zettler et al., 2020) found that emotionality and lower scores on "dark factor" personality traits were associated with higher willingness to accept restrictions to personal freedom in response to the COVID-19 pandemic. A survey experiment performed March 15-16 on COVID-19 public information campaigns (Everett et al., 2020) found that appealing to duty and responsibility had a modest effect on behavioural intentions, while appealing to virtue had a modest effect on trying to prevent infection spread. These studies suggest various factors that influence the public's response to pandemics, 
and indicate that we must understand the individual and motivational factors in order to improve a society's response to a pandemic.

\subsection{Factors related to perceived pandemic risk}

We see from the brief review above that recent pandemic research has emphasised whether the public see the contagion as threatening. The perceived risk for an event is an expression of the subjective understanding of the likelihood for the event, multiplied by the subjective understanding of the consequences of the event (Dowling \& Staelin, 1994; Renn, 1998). Human risk perception has been shown to deviate from an expected utility calculation (Mousavi \& Gigerenzer, 2014; Tversky \& Kahneman, 1979). This implies that when the public are informed about pandemic threat, they may subjectively perceive the threat to be higher or lower than the objective information implies. Thus, to predict and improve the public's response to a pandemic, we need to take into account factors that influence the perceived risk, such as decision frames, heuristics, cognitive and cultural bias.

Another factor of interest should be the public's behavioural intentions to comply with health authority advice on how individuals should act to limit the contagion. The advice tends to focus on personal hygiene (washing hands frequently and thoroughly), to avoid touching surfaces, to avoid social situations and proximity to others, and to limit unnecessary travel and work from home when possible. Although most members of the public may be expected to be familiar with such advice, they may vary in the extent to which they trust the advice and take it seriously, how they balance the advice against other interests, and whether they see the advice as limiting their individual freedom.

One may expect there to be individual variation in how serious the public perceives a given threat like the pandemic to be, and what propensity they have to respond to it (van der Pligt, 1998). Bish and Michie (2010) found that across studies, compliance to infection advice was predicted by the perceived susceptibility and severity of the disease and belief in efficacy of the advice (Agüero et al., 2011; Tooher et al., 2013). A factor such as dispositional optimism, in terms of positive expectancies for future outcomes (Carver \& Scheier, 2014), has been shown to influence the motivation and effort in handling a given challenge. The construct is also related to other psychological capacities, such as individuals' social support network (Prati \& Pietrantoni, 2009). An optimism bias (Sharot, 2011) or unrealistic optimism (van der Pligt, 1998) implies believing that oneself is less at risk than others are. This could prevent individuals from taking sufficient heed to the pandemic risks, despite being aware of them. However, some levels of optimism could also have individual benefits for mental health and for coping with the stressors of living through a prolonged pandemic, and could have societal benefits for maintaining services, commerce and activity. It could thus be of value to describe the public's optimism that they will be able to handle the challenges of the pandemic.

Finally, we are interested in the information gathering strategies that members of the public employ to understand the risks related to the pandemic, and to base their behaviour upon. For societal challenges like a pandemic, the individual's perceived risk will initially be strongly influenced by public risk communication and subsequent informal communication. Social trust, social amplification of trust, and affect heuristic have been shown to be important, and studies have tested the effect of referring to risk comparisons, social 
norms, moral messages, credibility and trust, visuals or manipulating mental models (Bier, 2001; Lancet, 2020; McComas, 2006).

\subsection{Research needs}

Prevention is more efficient than treatment in health economics. This adage may be especially true for pandemics, which can grow exponentially in a society over a relatively short time. Intervening in the early phase of the pandemic may have large benefits in limiting further contagion spread. The current data paper with descriptive statistics may inform us about how effective the public health information campaigns were in informing the public about the pandemic in its early phase, and the extent to which the public saw the pandemic as a threat and engaged in protective behaviours. The results can have consequences for interpreting the outcome of the pandemic and planning for how to handle future pandemics.

\subsection{Current study}

Here I will present the response distribution on some selected single items in a survey of a nationally representative sample in the early phases of the COVID-19 pandemic. More thorough review of variable indexes and associations will be tested in forthcoming publications. The report is thus descriptive and exploratory, and does not include confirmatory hypothesis testing. Subsequent papers and datasets from the project will be listed on the research project website (https://www.uib.no/en/pandrisk).

A preregistration of the data collection listed the items included in the current analysis: https://osf.io/umgnr/. Note however that the registered variable indexes will not be used in the current report, nor will any of the registered hypotheses be tested here. The overall survey measured a number of variables related to the pandemic from different theoretical perspectives (e.g. mental health, somatic health, sleep, economics, work conditions, democratic and judicial aspects). Based on the theoretical discussion above, the current paper presents some descriptive statistics from variables related to perceived probability, perceived consequences, behavioural intentions, and information gathering strategies.

\section{Methods}

\subsection{Participants}

The data presented here was collected as part of the "Norwegian Citizen Panel", which is a platform for internet surveys of public opinion in Norway. The panel has been fielded several times a year since 2013. The unit of analysis is individuals among the population of Norwegian citizens above the age of 18. The University of Bergen is responsible for running the panel, while the company ideas2evidence recruits participants, produces the survey and provides documentation. The Norwegian Social Science Data services (Norsk senter for forskningsdata, NSD) store and share the data. The actual sample size depended on the response rate, and was outside of the control of the researchers (no possibility for optional stopping).

Invitations to participate were sent out to 15,409 eligible respondents. The total sample size of eligible responses was $N=12,051$ (response rate $=78.2 \%$ ). This results in a $0.9 \%$ sample error for $95 \%$ confidence intervals given a sample proportion of $50 \%$. The full panel answered two of the survey items reported in the current paper. The panel was randomly split in three sub-samples that answered different sets of survey 
items, leading to a sample of $N=4,083$ that answered most of the survey items in the current paper (adjusted sample error of 1.5\%, see absolute number of responses in Table 1 at end of this manuscript).

Analysing for representativeness (see methodology report for details: https://osf.io/uebq7/) shows that the age group over 59 years are overrepresented by 15\%, while the age group 18-29 are underrepresented by $12 \%$ (stronger for men than for women). Those with university level education were overrepresented by $29 \%$, while those with no education or only elementary education were underrepresented by 19\%. Urban areas containing the country's three largest metropolitan areas were overrepresented by up to $4 \%$, while less urban areas in Eastern and Northern Norway were similarly underrepresented. The trends in representativeness is largely unchanged from previous panel waves, indicating that the timing and the topic of the wave had little effect on the representativeness. The dataset is provided with weighting variables to allow controlling for lack of representativeness.

\subsection{Data collection procedure}

Initial recruitment to the panel was done by postal mail, based on selections from the Norwegian Tax Administration registry. For the current data collection wave (Ivarsflaten et al., 2020), emails were sent out on March 20, 2020, with a follow-up email a few days later to those who had not logged into the survey or had not completed the survey. The survey was open for receiving responses until March 29, but the majority of the responses came within the first days. The timing of the data collection may be considered as the "early phase" of the COVID-19 pandemic in Norway, as the data collection started a week after the government had announced major intrusive "lock-down" measures to limit the contagion spread. This included measures such as barring public services and events and some limits on public transport services, closing schools and kindergartens, and strongly recommending self-isolation, keeping physical distance from non-family members (sometimes called "social distancing"), working from home and avoiding unnecessary travel. These measures were reported as being the most severe restrictions of personal freedom in Norway during peacetime. At the time of the survey there was extensive public debate about the likely severity of the pandemic, and the appropriateness of the measures.

In the presentation below the survey item texts have been translated to English and in some cases shortened or transformed. The original item texts in Norwegian and direct translation to English are available in Table 1 at end of this manuscript, which also shows the order of the items in the survey, and the answer distribution in absolute numbers. Most survey items were phrased as Likert-type statements to which the participants indicated their agreement on a five-point scale. In our text summary below, the two most extreme responses are taken to express agreement or disagreement to the statement. The full dataset is available here: https://osf.io/uebq7/, along with detailed methodology report and a codebook describing the variables.

\section{Descriptive results}

\subsection{Response distribution for perceived probabilities}

Four survey items were related to the participants' estimates about how likely or unlikely they thought it would be for the pandemic to cause various negative events. The items asked participants to assess 
probabilities from "Very low" to "Very high" for the current coronavirus outbreak to cause the events within the end of the year 2020 (as this was seen as a realistic upper limit of the duration of the outbreak at the time of data collection).

The top line in Figure 1 shows that the participants considered there to be a relative high probability for the average person to be infected by the coronavirus ( $46 \%$ of the panel say "Somewhat high" or "Very high", shown as red colours on right side of figure). The second line shows that considerably fewer (26\%) perceived there to be a high risk of being infected themselves. It should be noted that the answers to this question varied greatly across age. Only $9 \%$ of those older than 70 saw the risk as high, while $45 \%$ of those younger than 50 saw it as high. Given that older respondents are overrepresented in our sample (as described in section 2.1 above), the actual population average is thus higher than shown in the figure. The third line shows that quite few $(8 \%)$ believed that they were at risk of becoming seriously ill, while the fourth line shows that over half $(57 \%)$ believed that their lives could be significantly changed by the pandemic.

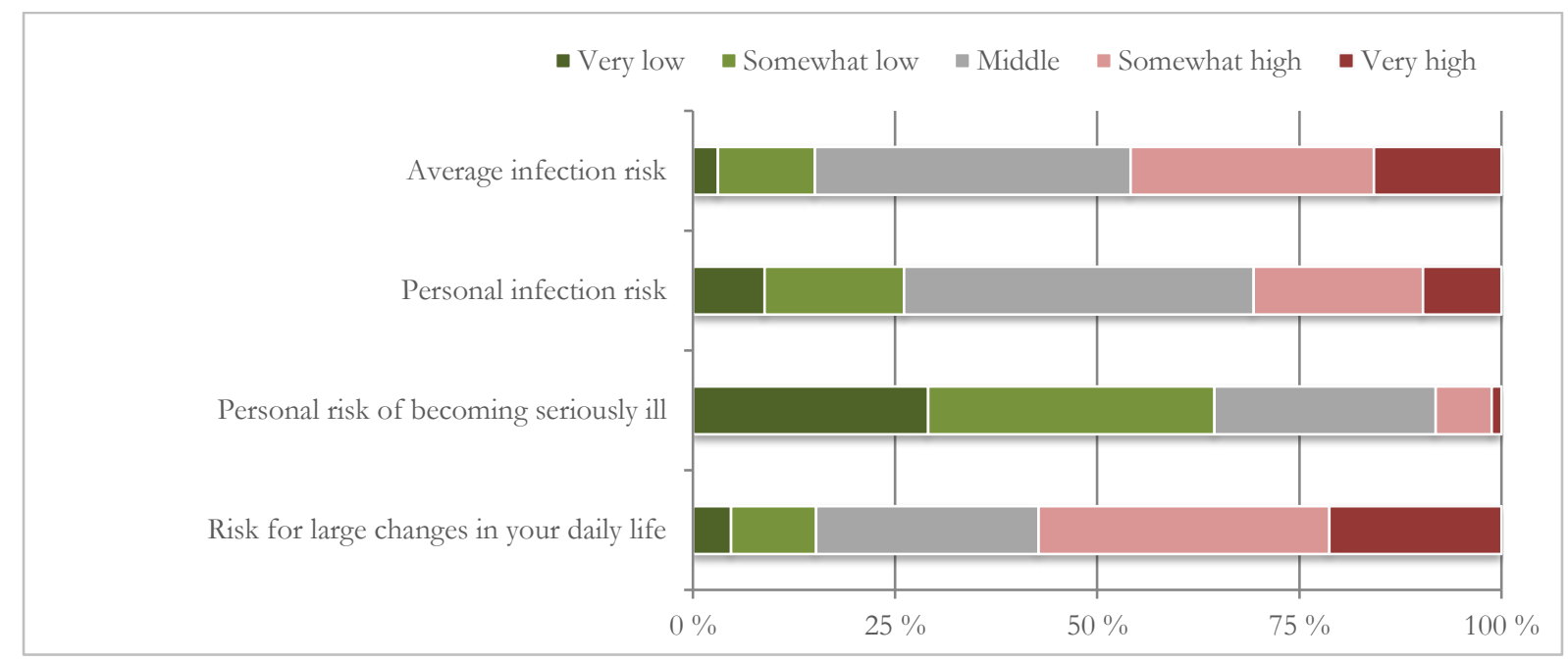

Figure 1: Answer distribution for estimated probabilities for various events to occur in 2020. See Table 1 for full item text (original and translated).

\subsection{Response distributions for perceived consequences}

There were five survey items about what consequences the participants thought the pandemic would have. These were related to medical outcomes and treatment, and whether participants worried about the pandemic and were optimistic about being able to handle it.

The top line in Figure 2 shows that about a third of the participants (red fields on the right side, 32\%) thought it would be very serious for them to be infected, while almost the same proportion (green fields on the left, 35\%) believed that they would be ok even if they were infected. This variability may reflect that participants consider themselves to have different vulnerabilities or belong to different risk groups (other items in the survey showed that $27 \%$ of the participants considered themselves to be particularly vulnerable for the virus, and 26\% lived with someone vulnerable). The second line in Figure 2 shows that a quarter of the participants $(26 \%)$ were concerned about being infected, while the third line shows that far more $(70 \%)$ worried that someone in their family may become infected. The fourth line shows that a vast majority (90\%) were confident that they will receive good treatment if they become acutely and seriously ill (only 6\% do 
not think so). The final line shows that most (79\%) were optimistic that they have the resources to deal with the challenges they may face in the pandemic (while 3\% were pessimistic).

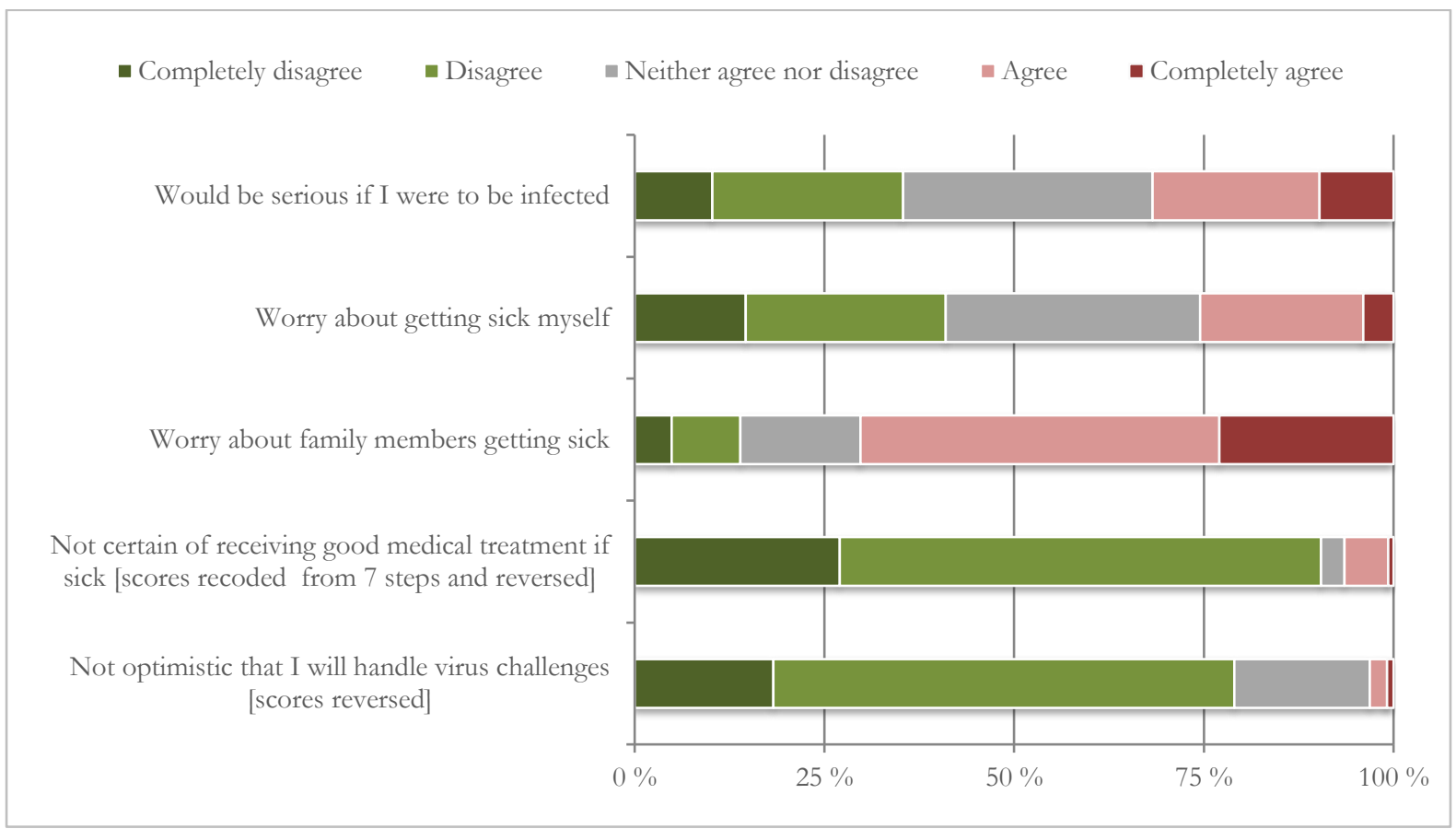

Figure 2: Answer distribution for survey items about consequences. Note that to facilitate comparison with the other items, both item phrasing and scoring have been reversed the fourth and fifth item. Further, the fourth item has been aggregated from a seven-point scale of "certainty" that was not explicitly worded to refer to the current pandemic. See Table 1 for non-transformed items and results.

\subsection{Response distributions for behavioural intentions}

There were four survey items about whether participants trust, believe and follow the health authorities' advice about how to act to limit the pandemic contagion. The first of these items provided examples of the official public health information that had been widely circulated in Norway at the time, and as examples it mentioned actions such as washing hands, avoiding travel and social situations, keeping physical distance to others and to avoid touching surfaces.

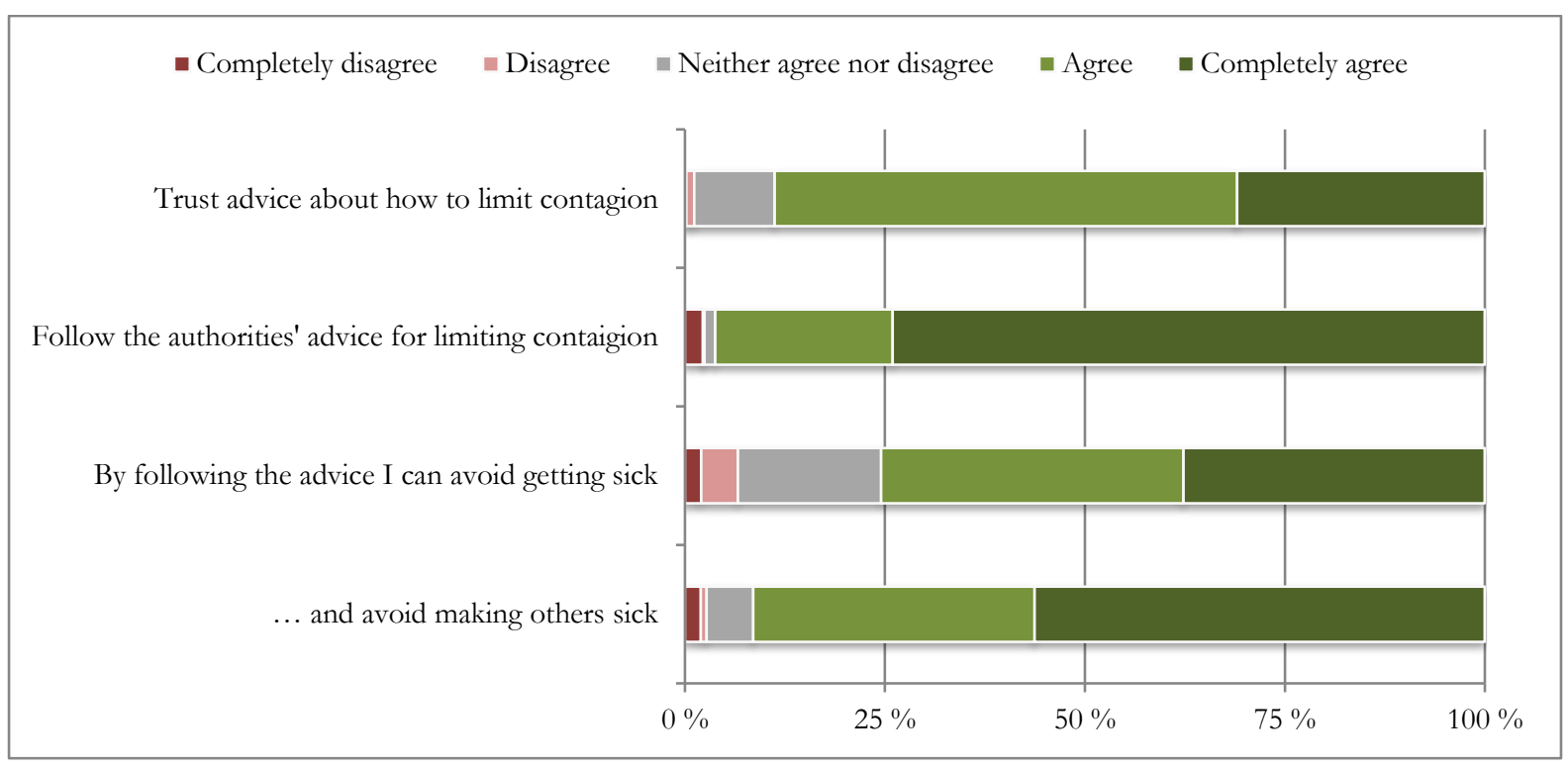

Figure 3: Answer distribution for survey items about behavioural intentions. 
The first line in Figure 3 shows that the large majority trusted the advice (89\% agree, 1\% disagree). The second line shows that almost everyone (96\%) said that they were doing their best to comply with the advice. The third line shows that most people believed that following the advice would prevent them from becoming sick (74\% agree, 7\% disagree), while the fourth line shows that somewhat more believed that following the advice would prevent them from making others sick (91\% agree, 3\% disagree).

\subsection{Response distributions for information gathering}

There were four survey items about how the participants gather and evaluate health information. A preceding item (not shown here) about being familiar with general advice made it clear that the first two items were about the general health advice from the authorities (not related to the ongoing pandemic), and examples referred to advice about diets and influenza vaccine. There were two subsequent survey items specifically about trusting information about the pandemic.

The first line in Figure 4 shows that almost all participants (96\%) trusted the health authorities in general (while not mentioning the pandemic), and the second line shows that the majority (61\%) said that they tend to comply with the health authorities' general advice. The third line shows that almost all participants $(98 \%)$ thought it was important that the information about the pandemic comes from a reliable source. The bottom line shows that a few (7\%) believed that information about the coronavirus is deliberately kept hidden from us, while most (76\%) do not think so.

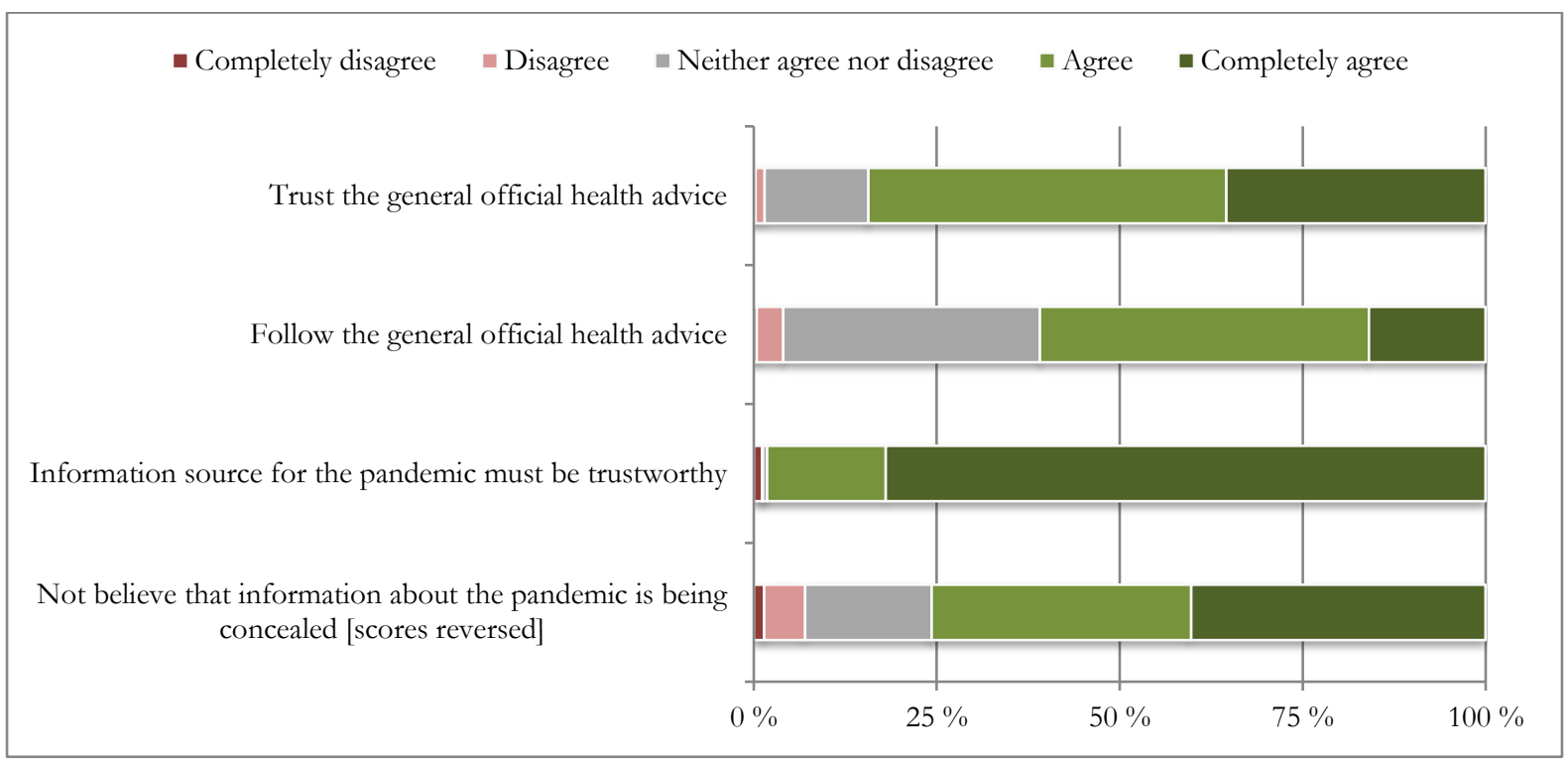

Figure 4: Answer distribution for survey items about behavioural intentions. Note that the two first items were asked in relation to "normally" trusting and following general health advice, where advice about diet and influenza vaccine was provided as examples. The final item has had phrasing and scoring reversed.

\section{Discussion}

\subsection{Perceived probabilities}

The evaluation of probabilities of various outcomes of the pandemic indicate that the Norwegian public had a realistic view of the pandemic that was in line with the experts' advice at the time. The COVID-19 disease poses a modest medical risk to most people, and only a minority thinks there is a considerable risk for them to be infected. It should be noted that it is more common to think the average person is at risk, 
than to think that oneself is at risk. Such a tendency to believe oneself to be safer than others is consistent with an optimistic bias (Sharot, 2011).

While few consider themselves to be at risk for infection, fewer still believe they are at risk of becoming seriously sick. This is again in line with expert estimates that a virus infection will not result in serious medical conditions for most of the population. On the other hand, a majority of the participants believe that the pandemic can have serious consequences for the society in general, and can greatly affect their dayto-day life. This view also appears to be well attuned with expert analyses, as estimates at the time was to expect large effects on the economy, working from home and job losses, and closing of public services, transport, commerce and cultural arrangements for much of the year 2020. The following months confirmed that the pandemic influenced most aspects of our daily lives.

It is noteworthy that perceived risk varied greatly with age of the participant. Further, the age effect was non-intuitive, as older participants that may be more vulnerable for the pandemic stated markedly lower perceived probability for becoming infected. This paradoxical effect may be due to factors such as lack of information, psychological defence mechanisms, or a sense of fatalism among the elderly. However, it could also be that while they are medically more at risk for infection or disease given similar exposure, the elderly are more careful in their behaviour, and thus could be correct in assuming that they are less at risk. This would be an important avenue for further research.

\subsection{Perceived consequences}

The responses about perceived consequences of the pandemic indicate that some worry about the virus, but most appear to be carefully optimistic. Only a few are worried for their own sake, which may correspond to the low perceived probability of becoming seriously ill (as discussed in section 4.1), but far more are worried about family members being infected. This is understandable as many will have extended family members among the elderly or in other groups for which the virus constitutes a larger risk. It may also be that parents are worried about their children being subject to infection and becoming sick, although relatively few children were infected. Further, most people have more than one family member they may think of when answering this question. An aggregation of the probabilities would result in envisioning a higher probability for any member of their family to be infected than of themselves being infected, even if they see the relative probability per individual to be similar.

Most participants are confident that they will receive good medical treatment if they should become seriously ill. This indicates a high level of trust in the public health system in the Norwegian population. It should be noted that in the period of data-collection there were widely reported concerns that in a worstcase pandemic outbreak the public health systems would become overloaded, and there were reports at the time of this happening in other countries (Feuer, 2020).

Finally, most of the participants also expressed that they believed they would be able to cope with the challenges that the pandemic may give them. This may express that the population had an overall sense of optimism and belief in their own resources to manage the pandemic. This appears to indicate high levels of optimism, resiliency and hardiness for this issue (Beasley et al., 2003, 2003; Carver \& Scheier, 2014; Maddi, 2006). It should be noted that some do not agree that they will be able to handle the challenges, which may 
reflect both the individual variation in general dispositions found in the literature, and actual variation in health, economy and other resources related to pandemic challenges.

\subsection{Behavioural intentions}

The behavioural intentions to comply with the infection prevention advice largely presents a positive and uplifting image. Most participants indicate that they trust, believe in and comply with the health authorities' advice. This indicates that the public health information had been effective in making the public familiar with how to limit the infection, and that the public is highly motivated to comply with the advice. Since it was shown in section 4.2 that few see themselves as being at significant risk, their intention to comply with the advice may be due to prosocial motives rather than self-interest.

It should be noted that somewhat more participants believe that following the advice will be effective in preventing them from making others sick, than the number of participants that believe that following the advice will prevent themselves from becoming sick. This may reflect the relationship discussed in section 4.1, that most people consider the risk to be smaller for themselves than it is for others. As they see their personal risk to be somewhat lower, there is a lower baseline for the advice to be effective, and they may see the behaviour to be more beneficial for others than for themselves. This could also indicate that advice compliance was at least partly prosocially motivated.

\subsection{Information gathering}

Most of the participants appear to be careful and critical in the way they gather information about the pandemic, and they trust and listen to the health authorities for general health information. As discussed in section 4.3, they trust and comply with health authority advice regarding the pandemic. Almost all state that it is important for them that information about the pandemic comes from a trustworthy and reliable source (although we have not measured what they consider to be reliable sources). This may function as a safeguard against exposure to misinformation in social media or fringe media.

Finally, quite few of the participants believed that information about the pandemic was being intentionally concealed from them. A belief that regional or national authorities conceal information from their public may be an expression of suspicion and scepticism, bordering on conspiracy thinking. It should be noted that the survey item is somewhat open for interpretation, as participants that responded that information has intentionally been concealed may have been thinking of the actions of other governments. For example, it was widely circulated at the time that the Chinese government had not shared all details fully or in a timely manner about how they had handled the pandemic (Campbell \& Gunia, 2020; Corera, 2020). Dedicated measures are needed to estimate conspiratorial thinking about the pandemic.

\subsection{Limitations}

It should be noted that due to having little time to prepare the study and limited space available in the panel survey, the current study has not used validated scales to measure the theoretical constructs, and the data presented here relies on ad-hoc single-item measures. Further, although longitudinal measures are planned, the current results are from a cross-sectional approach, which limits any conclusions about the causal relationships between the variables. Finally, it should be mentioned that this was a survey of behavioural intentions rather than objective measures of actual behaviour. There may be several reasons why 
participants could act differently from their self-reported intentions. The limits to representativeness should be kept in mind when interpreting the results, in particular the overrepresentation of older and higher educated participants. A fundamental assumption for the research project is that perceived risk motivates individuals to comply with advice to limit the contagion. However, there could also be more complex causal relationships, for example that individuals that see themselves as behaving more carefully perceive the risk for themselves to be lower due to less exposure to the contagion.

\subsection{Conclusion and further research}

We performed a survey of perceived risk and behavioural intentions towards the coronavirus pandemic during its early phase in a representative sample of 4,083 Norwegians. The overall impression from the survey is that the public had realistic and carefully optimistic estimates of probabilities and consequences of the pandemic, and that they trusted and followed the advice about behaviour that would limit the contagion.

The level of trust in the advice content, trust in the advice source, belief in advice efficiency, and intention to comply with the advice, could be said to indicate that the Norwegian population has a positive attitude to the advice (as defined by Breckler, 1984). Based on assumptions that attitudes and intentions determine behaviour (e.g. Ajzen \& Fishbein, 1980), forthcoming publications will examine the association between advice attitude and following the infection control measures.

The public perception of how the early phase of the pandemic was handled in Norway appears to correspond with the descriptive statistics provided here. On a press conference on April 7 (Treloar, 2020) the health authorities concluded that the behavioural measures had been effective in limiting the spread of the coronavirus in the preceding weeks. The credit for this outcome was placed on the public's embrace of the health authority advice. It should be emphasized that the current study presents the Norwegian public's subjective view of the pandemic in late March 2020. It is likely that similar measures in the later phases of the pandemic or measures of actual behaviour would indicate a higher perceived threat, less optimism and lower compliance.

We plan to do follow-up data collections using the same survey panel throughout 2020, which will allow us to identify different trajectories of how perceived risk, attitudes and behavioural intentions develop over time. The present and subsequent data collection rounds will be subjected to confirmatory and exploratory analyses to test for associations between the variables and their development over time. This will give us a better basis for drawing conclusions about causal relationships between the variables. Among the relationships that will be explored, we will be interested in relationships between individual and collective motivations to comply with the infection advice, and in how worry at earlier stages of the pandemic correspond to long-term mental health and medical outcomes.

\section{Acknowledgements}

I am grateful to the researchers at University of Bergen that have been involved in the "Norwegian Citizen Panel" collaboration, in particular Elisabeth Ivarsflaten and Erla Løvseth, and to members of the Operational Psychology Research Group that joined in planning the data collection. A special thanks goes to Hege Høivik Bye for reading and commenting on an earlier version of the manuscript. As editor for 
Collabra: Psychology, Simine Vazire provided thoughtful comments and suggestions that helped improve the manuscript. I am grateful to all those who have responded to the panel survey.

Data was collected as part of the COVID-19 extraordinary data collection of the "Norwegian Citizen Panel”, collected in March 2020 (Ivarsflaten et al., 2020). The Norwegian Citizen Panel is funded by the University of Bergen and the Trond Mohn Foundation. The data are produced by the University of Bergen and made available by ideas2evidence. The current manuscript has been prepared as part of the PANDRISK research project funded by the Trond Mohn Foundation, project number TMS2020TMT08. These parties have not reviewed the current publication and are not responsible for the accuracy of the results and should not be seen as endorsing the statements in the manuscript.

\section{References}

Agüero, F., Adell, M. N., Pérez Giménez, A., López Medina, M. J., \& Garcia Continente, X. (2011). Adoption of preventive measures during and after the 2009 influenza A (H1N1) virus pandemic peak in Spain. Preventive Medicine, 53(3), 203-206. https://doi.org/10.1016/j.ypmed.2011.06.018

Ajzen, H., \& Fishbein, M. (1980). Understanding attitudes and predicting social behavior. Prentice-Hall. https://www.scienceopen.com/document?vid=c20c4174-d8dc-428d-b352-280b05eacdf7

American Perspectives Survey. (2020, April 2). Fear, frustration, and faitb: Americans respond to the coronavirus outbreak. American Enterprise Institute - AEI. https://www.aei.org/research-products/report/fear-frustration-and-faith-americansrespond-to-the-coronavirus-outbreak/

Barr, M., Raphael, B., Taylor, M., Stevens, G., Jorm, L., Giffin, M., \& Lujic, S. (2008). Pandemic influenza in Australia: Using telephone surveys to measure perceptions of threat and willingness to comply. BMC Infectious Diseases, 8(1), 117. https://doi.org/10.1186/1471-2334-8-117

Beasley, M., Thompson, T., \& Davidson, J. (2003). Resilience in response to life stress: The effects of coping style and cognitive hardiness. Personality and Individual Differences, 34(1), 77-95. https://doi.org/10.1016/S0191-8869(02)00027-2

Bier, V. M. (2001). On the state of the art: Risk communication to the public. Reliability Engineering \& System Safety, 71(2), 139-150. https://doi.org/10.1016/S0951-8320(00)00090-9

Bish, A., \& Michie, S. (2010). Demographic and attitudinal determinants of protective behaviours during a pandemic: A review. British Journal of Health Psychology, 15(4), 797-824. https:// doi.org/10.1348/135910710X485826

Breckler, S. J. (1984). Empirical validation of affect, behavior, and cognition as distinct components of attitude. Journal of Personality and Social Psychology, 47(6), 1191-1205. https://doi.org/10.1037/0022-3514.47.6.1191

Bults, M., Beaujean, D. J., de Zwart, O., Kok, G., van Empelen, P., van Steenbergen, J. E., Richardus, J. H., \& Voeten, H. A. (2011). Perceived risk, anxiety, and behavioural responses of the general public during the early phase of the Influenza A (H1N1) pandemic in the Netherlands: Results of three consecutive online surveys. BMC Public Health, 11(1), 2. https://doi.org/10.1186/1471-2458-11-2

Campbell, C., \& Gunia, A. (2020, April 1). Can We Believe Any of China's Coronavirus Numbers? | Time. https://time.com/5813628/china-coronavirus-statistics-wuhan/ 
Carver, C. S., \& Scheier, M. F. (2014). Dispositional optimism. Trends in Cognitive Sciences, 18(6), $293-299$. https://doi.org/10.1016/j.tics.2014.02.003

Corera, G. (2020, April 7). Can we trust China claims of virus success? BBC News. https://www.bbc.com/news/world-asia-china52194356

Dowling, G. R., \& Staelin, R. (1994). A Model of Perceived Risk and Intended Risk-handling Activity. Journal of Consumer Research, 21(1), 119-134. https://doi.org/10.1086/209386

Everett, J. A., Colombatto, C., Chituc, V., Brady, W. J., \& Crockett, M. (2020). The effectiveness of moral messages on public health behavioral intentions during the COVID-19 pandemic. https://doi.org/10.31234/osf.io/9yqs8

Feuer, W. (2020, March 20). WHO officials warn health systems are 'collapsing' under coronavirus: 'This isn't just a bad flu season'. CNBC. https://www.cnbc.com/2020/03/20/coronavirus-who-says-health-systems-collapsing-this-isnt-just-a-bad-fluseason.html

Ivarsflaten, E., Eidheim, M., \& Løvseth, E. (2020). Norwegian Citizen Panel, FT1. Data collected by ideas2evidence for the Norwegian Citizen Panel at the University of Bergen, extra-ordinary fast-track round 1, Bergen.

Jones, J. H., \& Salathé, M. (2009). Early Assessment of Anxiety and Behavioral Response to Novel Swine-Origin Influenza A(H1N1). PLoS ONE, 4(12). https://doi.org/10.1371/journal.pone.0008032

Lancet, T. (2020). COVID-19: Fighting panic with information. The Lancet, 395(10224), 537. https://doi.org/10.1016/S01406736(20)30379-2

Maddi, S. R. (2006). Hardiness: The courage to grow from stresses. The Journal of Positive Psychology, 1(3), 160-168. https://doi.org/10.1080/17439760600619609

McComas, K. A. (2006). Defining Moments in Risk Communication Research: 1996-2005. Journal of Health Communication, 11(1), 75-91. https://doi.org/10.1080/10810730500461091

Mousavi, S., \& Gigerenzer, G. (2014). Risk, uncertainty, and heuristics. Journal of Business Research, 67(8), 1671-1678. https://doi.org/10.1016/j.jbusres.2014.02.013

Prati, G., \& Pietrantoni, L. (2009). Optimism, Social Support, and Coping Strategies As Factors Contributing to Posttraumatic Growth: A Meta-Analysis. Journal of Loss and Trauma, 14(5), 364-388. https://doi.org/10.1080/15325020902724271

Renn, O. (1998). Three decades of risk research: Accomplishments and new challenges. Journal of Risk Research, 1(1), 49-71.

Rubin, G. J., Amlôt, R., Page, L., \& Wessely, S. (2009). Public perceptions, anxiety, and behaviour change in relation to the swine flu outbreak: Cross sectional telephone survey. The BMJ, 339. https://doi.org/10.1136/bmj.b2651

Sharot, T. (2011). The optimism bias. Current Biology, 21(23), R941-R945. https://doi.org/10.1016/j.cub.2011.10.030

Tooher, R., Collins, J. E., Street, J. M., Braunack-Mayer, A., \& Marshall, H. (2013). Community knowledge, behaviours and attitudes about the 2009 H1N1 Influenza pandemic: A systematic review. Influenza and Other Respiratory Viruses, 7(6), 1316-1327. https://doi.org/10.1111/irv.12103

Treloar, S. (2020, April 7). Norway Loosening Restrictions as Virus Seen Under Control. Bloomberg. https://www.bloomberg.com/news/articles/2020-04-07/norway-starts-easing-restrictions-as-virus-seen-under-control

Tversky, A., \& Kahneman, D. (1979). Prospect Theory: An analysis of decision under risk. Econometrica, 47(2), $263-291$. https://doi.org/10.1142/9789814417358_0006 
van der Pligt, J. (1998). Perceived risk and vulnerability as predictors of precautionary behaviour. British Journal of Health Psychology, 3(1), 1-14. https://doi.org/10.1111/j.2044-8287.1998.tb00551.x

Walter, D., Böhmer, M. M., Reiter, S., Krause, G., \& Wichmann, O. (2012). Risk perception and information-seeking behaviour during the 2009/10 influenza A(H1N1)pdm09 pandemic in Germany. Eurosurveillance, 17(13), 20131. https://doi.org/10.2807/ese.17.13.20131-en

Wise, T., Zbozinek, T. D., Michelini, G., Hagan, C. C., \& Mobbs, D. (2020). Changes in risk perception and protective behavior during the first week of the COVID-19 pandemic in the United States. Psy_Arxiv. https://doi.org/10.31234/osf.io/dz428

Zettler, I., Schild, C., Lilleholt, L., \& Böhm, R. (2020). Individual differences in accepting personal restrictions to fight the COVID19 pandemic: Results from a Danish adult sample. Psy Arxiv. https://doi.org/10.31234/osf.io/pkm2a

Zickfeld, J., Schubert, T., Herting, A. K., Grahe, J., \& Faasse, K. (2020). Correlates of Health-Protective Behavior During the Initial Days of the COVID-19 Outbreak in Norway. https://doi.org/10.31234/osf.io/6vgf4 
Table 1: Original item text and response distribution in absolute numbers

Order in survey

and variable name

11 , risk

infection_genera

1 , risk_

infection_self

12 , risk

become_sick_self

13 , risk

changed_self

Order in survey

and variable name

14 , trait

virus_risk

3 , consequences

concern_infected_self

4 , consequences

concern_infected_family

2 , trait_

trust_medical_treatment

15 , trait

handle_challenges
Item text (original Norwegian and translated)

Figure 1: Perceived probabilities

Hvor stor anser du risikoen for at i løpet av 2020 vil... en

gjennomsnittlig voksen bli smittet?

How high do you consider the riske to be that in 2020... an average adult in

Norway will be infected?

Hvor høy eller lav tror du at risikoen er for at du selv blir smittet av koronaviruset i løpet av 2020?

How bigh or low do you think the risk is that you will be infected by the

coronavirus in 2020?

Hvor stor anser du risikoen for at i løpet av 2020 vil... du bli alvorlig syk?

How bigh do you consider the risk to be that in 2020... you will become seriously ill from the coronavirus?

Hvor stor anser du risikoen for at i løpet av 2020 vil... din hverdag bli mye endret?

How high do you consider the risk to be that in 2020... your everyday life will be significantly changed due to the coronavirus?

Figure 2: Perceived consequences

Det ville vært svært alvorlig for meg dersom jeg ble smittet av viruset.

It would be very serious for me if I got infected by the virus.

Jeg bekymrer meg for at jeg kommer til å bli smittet av koronaviruset.

I worry that I will be infected by the coronavirus.

Jeg bekymrer meg for noen i min familie kommer til å bli smittet av koronaviruset.

I worry that someone in my family is going to be infected by the coronavirus.

Hvor trygg føler du deg på at du vil få god behandling i det offentlige helsesystemet hvis du blir akutt og alvorlig syk?

How certain are you that you will receive good treatment in the public healthcare system if you should become suddenly and seriously ill?

Jeg er optimistisk til at jeg kommer til å håndtere de utfordringene som koronautbruddet vil gi meg

I'm optimistic that I will deal with the challenges that I will face due to the coronavirus.

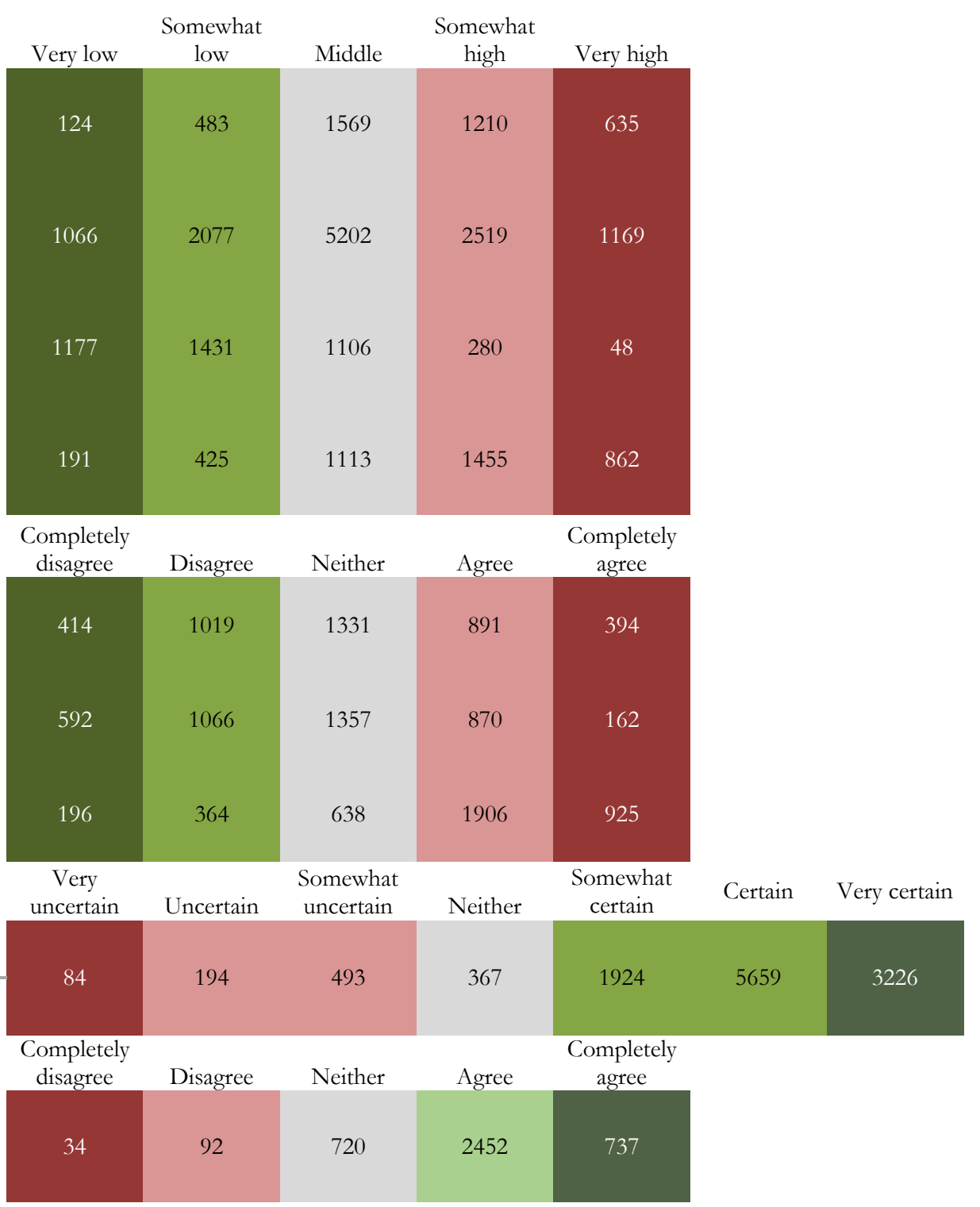


Table 1 continued.

\section{Order in survey Item text (original Norwegian and translated)}

and variable name Figure 3: Compliance

Jeg giør mitt beste for å følge de ulike rådene fra helsemyndigheter for å begrense smittefaren (vasker

5 , compliance

hendene ofte, unngår reiser og situasjoner med andre mennesker, holder avstand og unngår å ta på ting)

general

I do my best to follow the various advice from health authorities to limit the riske of infection (washing hands frequently,

avoiding travel and situations with other people, keeping distance and avoiding touching things)

6, compliance

efficiency_self

Ved å følge smittevernrådene vil jeg unngå å bli syk

7, compliance_ efficiency_others

By following the infection prevention advice, I will avoid getting sick

Ved å følge smittevernrådene vil jeg unngå å gjøre andre syke

8, compliance

By following the infection prevention advice, I will avoid making others sick.

trust_abt_pandemic

I hvilken grad stoler du på rådene fra helsemyndighetene? [stilt i sammenheng med smittevernråd]

\section{Order in survey}

\section{and variable name Figure 4: Information gathering}

I hvilken grad stoler du normalt på slike råd fra helsemyndighetene [viser til generelle helseråd, hvor kosthold og influensavaksine gis som eksempler]

16, compliance_ To what extent do you normally trust such advice from bealth authorities [in reference to general health advice, with diet and trust_abt_health flu vaccines given as examples?

I hvilken grad følger du normalt råd fra helsemyndighetene [viser til generelle helseråd, hvor kosthold og influensavaksine gis som eksempler]

17, compliance_ $\quad$ To what extent do you normally follow the advice from the health authorities [in reference to general health advice, with diet abt_health and flu vaccines given as examples]

9, information_-
pandemic_credible

Det er viktig for meg at informasjonen om sykdommen kommer fra en troverdig kilde.

It is important to me that information about the disease comes from a credible source

10 , information

Jeg tror at informasjon om koronaviruset bevisst holdes skjult for oss.

pandemic_concealed I believe that information about the coronavirus is deliberately concealed from us

\begin{tabular}{|c|c|c|c|c|}
\hline $\begin{array}{c}\text { Completely } \\
\text { disagree }\end{array}$ & Disagree & Neither & Agree & $\begin{array}{c}\text { Completely } \\
\text { agree }\end{array}$ \\
\hline 91 & 9 & 53 & 900 & 3002 \\
\hline 83 & 185 & 726 & 1532 & 1528 \\
\hline 80 & 29 & 237 & 1426 & 2282 \\
\hline 8 & 39 & 407 & 2345 & 1255 \\
\hline $\begin{array}{c}\text { Completely } \\
\text { disagree }\end{array}$ & Disagree & Neither & Agree & $\begin{array}{c}\text { Completely } \\
\text { agree }\end{array}$ \\
\hline 8 & 39 & 407 & 2345 & 1255 \\
\hline 14 & 131 & 1255 & 1609 & 571 \\
\hline 47 & 4 & 23 & 656 & 3319 \\
\hline 1623 & 1429 & 699 & 224 & 58 \\
\hline
\end{tabular}

Table 1: Item order, theme, original and translated item text, and answer distribution in absolute numbers. Please note that items 2, 10 and 15 have reverse colouring compared to the other items in their category to reflect that agreement with the claim has the opposite relationship to the variable, and that the scores have been reversed to produce Figures 2 and 4. 